\title{
Alteration Characteristics Of IImenites From South India
}

\author{
D. S. Rao ${ }^{1}$, T. V. Vijayakumar', S. Prabhakar ${ }^{1}$, G. Bhaskar Raju ${ }^{1}$ and T.K.Ghosh ${ }^{2}$ \\ ${ }^{1}$ National Metallurgical laboratory - Madras Centre, \\ CSIR Madras Complex, Taramani Chennai - 600 113, India \\ Email:nmldsr@yahoo.co.in \\ ${ }^{2}$ Institute Instrumentation Centre, \\ IIT, Roorkee, INDIA
}

\begin{abstract}
:
Two different placer samples from the Navaladi and Surungudi area of Teri, Tamilnadu, in southern India, were collected and characterized in terms of their heavy mineral content. Mineralogical analysis on both the samples revealed the presence of high amounts of garnet and ilmenite. The alteration characteristics of ilmenite from these deposits were investigated by optical and electron probe microanalysis. Optical microscopic studies revealed that the alteration of ilmenite was seen to proceed along grain boundaries and/or fractures resulting in an amorphous to crypto- or microcrystalline mass resembling leucoxene. The alteration is in the nascent stage. Mineral chemistry by electron probe micro-analysis revealed the enrichment of $\mathrm{TiO}_{2}, \mathrm{MgO}$, $\mathrm{Al}_{2} \mathrm{O}_{3}, \mathrm{Cr}_{2} \mathrm{O}_{3}, \mathrm{SiO}_{2}, \mathrm{~V}_{2} \mathrm{O}_{5}$ and $\mathrm{Na}_{2} \mathrm{O}$ in the altered products and loss of iron oxide and manganese oxide from the ilmenite grains during weathering leading to the formation of leucoxene. Similarly EPMA studies on garnet indicated that it is of the almandine variety.

This study reveals that the alteration of ilmenite by weathering leads to unstable phases, with complex elemental distribution patterns. The physico-chemical characteristics of the mineral and, in turn, the down-stream metallurgical processing are affected by such alteration processes.
\end{abstract}

Key words: Placer Ilmenite, Alteration, EPMA, Navaladi, Teri

\section{INTRODUCTION}

Minerals formed by geological processes and deposited at favorable locales give rise to economic deposits. These minerals, when subjected to post-depositional physicochemical changes, undergo certain chemical reconstitution known as alteration. This causes either enrichment or depletion of certain element(s), which has a bearing on the exploration/exploitation of minerals. Alteration is primarily a disintegrative reconstitutive process where the distribution of elements takes place depending on the prevalent Eh-pH conditions and the totality of the geological environment. The alteration process gives rise to distinct phases, i.e. a parent or resistate phase and the newly formed or neoformed authigenic phase distributed in an orderly or disorderly manner along with the resistate ${ }^{[1]}$. Most alteration leads to thermodynamically unstable, incomplete, irreversible phases that are extremely complex in elemental composition. Consequently, the physical and chemical characteristics such as bulk density, porosity, grain density, 
hardness, magnetic susceptibility and other properties are affected. These changes may effect the down stream beneficiation/metallurgical processing of the deposit.

Ilmenite $\left(\mathrm{FeTiO}_{3}\right)$, an important and most abundant mineral of titanium, occurs in India along the coastal beach sands of Orissa, Andhra Pradesh, Tamilnadu, Maharastra and Kerala states. The degree of alteration due to weathering is significant and is independent of the provenance. Hence, it attracts the attention of scientists in different disciplines with totally different approaches ${ }^{[2-5]}$. Several workers have studied ilmenite from across the world to assess the qualitative variation from deposit to deposit ${ }^{[6-9]}$, Many articles were published on the alteration of ilmenite ${ }^{[4,10-13]}$. In the present study, two different run of mine (ROM) samples, one from Navaladi (N8 ${ }^{\circ} 14{ }^{\prime} 15^{\prime \prime}-8^{\circ} 16^{\prime} 23^{\prime \prime}$ Lat.

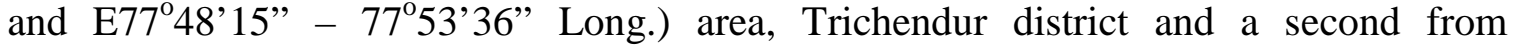
Surangudi ( $9^{\circ} 06^{\prime} 00^{\prime}-9^{\circ} 10^{\prime} 08^{\prime}$ ' Lat. and E78 $19^{\prime} 15^{\prime}$ - $78^{\circ} 26^{\prime} 40^{\prime \prime}$ Long.) area of Teri, Tuticorin district Tamilnadu (south India) were investigated with reference to their heavy mineral content and the alteration characteristics of ilmenite using optical and EPMA techniques.

\section{MATERIALS AND METHODS}

Representative placer samples were collected from the Navaladi as well as the Teri area for this characterization study. Both the samples were processed for the estimation of total heavy mineral (THM) content using Bromoform $\left(\mathrm{CHBr}_{3}\right.$; specific gravity 2.89), as a media for separation of heavier fractions from the lighter. Further, the samples were subjected to magnetic separation using Permroll (20,000 Gauss) to separate magnetic and non-magnetic fractions. Petro-mineralogical studies were carried out, by stereomicroscopy as well as with a LEITZ Orthoplan optical microscope, to identify the components of the total heavy mineral content. Magnetic and non-magnetic fractions of heavy minerals were analysed for their mineral chemistry with the help of a JEOL EPMA Super Probe JXA - 8600 model, with an accelerating voltage of $15 \mathrm{kV}$ and a specimen current of $2 \times 10^{-8}$ amps, using SPI mineral standards. Particle size analysis was carried out using a laser diffraction particle size analyzer (CILAS 1180, France).

\section{RESULTS}

\section{Magnetic separation:}

Magnetic separation studies of the ROM samples from the Navaladi and Teri areas indicated $33.22 \%$ and $35.70 \%$ of magnetic minerals respectively (Table 1 ).

\section{Heavy media separation:}

Heavy media separation studies of the ROM sample from the Navaladi area have indicated that the sample contains around $34.20 \%$ of total heavies while the same type of 
study of the Teri sample indicated $37.26 \%$ heavies (Table 1). The higher amount of heavy minerals (by heavy media separation) as compared to the magnetic separation fractions is due to the rutile and zircon content in the sample, which did not report in the magnetic fractions due to their non-magnetic nature.

Table 1: Distribution of Magnetic \& non-magnetic and heavy \& light fractions.

\begin{tabular}{|l|c|c|c|c|}
\hline \multirow{2}{*}{ Area } & \multicolumn{2}{|c|}{ \% Distribution } & \multicolumn{2}{c|}{ \% Distribution } \\
\cline { 2 - 5 } & Magnetic & Non-magnetic & Heavy & Light \\
\hline Navaladi & 33.22 & 66.78 & 34.20 & 65.80 \\
\hline Teri & 35.70 & 64.30 & 37.26 & 62.74 \\
\hline
\end{tabular}

\section{Particle size distribution:}

Particle size distribution of the ROM sample as well as magnetic and non-magnetic products, from Navaladi area, (Figure -1) shows that the magnetic fraction has a finer in particle size distribution than the non-magnetic and ROM sample. The particle size distribution of the ROM sample as well as magnetic and non-magnetic products, from Teri area, (Figure - 2)

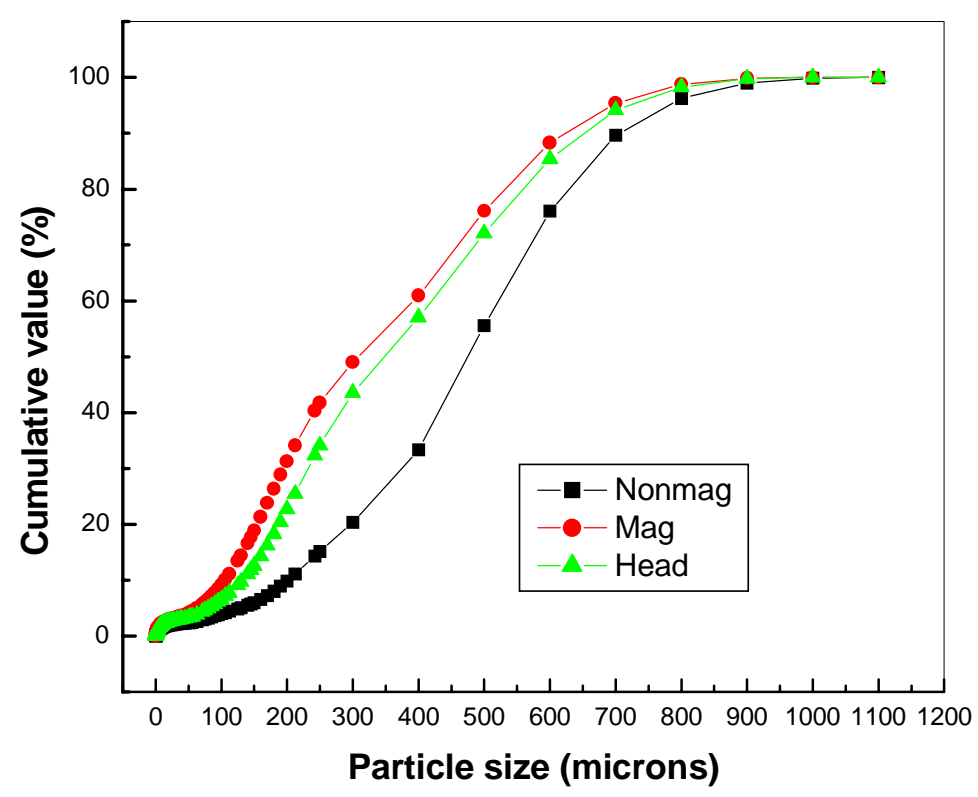

Figure.1: Particle size analysis of Navaladi ROM sample along with magnetic and non-magnetic fractions

shows a similar

trend (Table 2), although the Teri magnetic fraction is much finer than the non-magnetic and ROM fractions. In addition, the mean particle size of the magnetic fraction of the Teri sample was 75 microns while the Navaladi magnetic sample had a mean particle size of 341 microns. Overall, the mean particle size of the Teri ROM and separated fractions was finer than the Navaladi ROM and fractions. 


\section{Mineral distribution:}

Stereo-

microscopic

studies suggest

that the garnet is

the major phase

in the magnetic

fraction along

with lesser

amounts of

ilmenite in the

case of Navaladi

(Figures - 3a and

3b) while

ilmenite forms

the major phase

with garnet a

minor phase for

the Teri sample.

Zircon and rutile

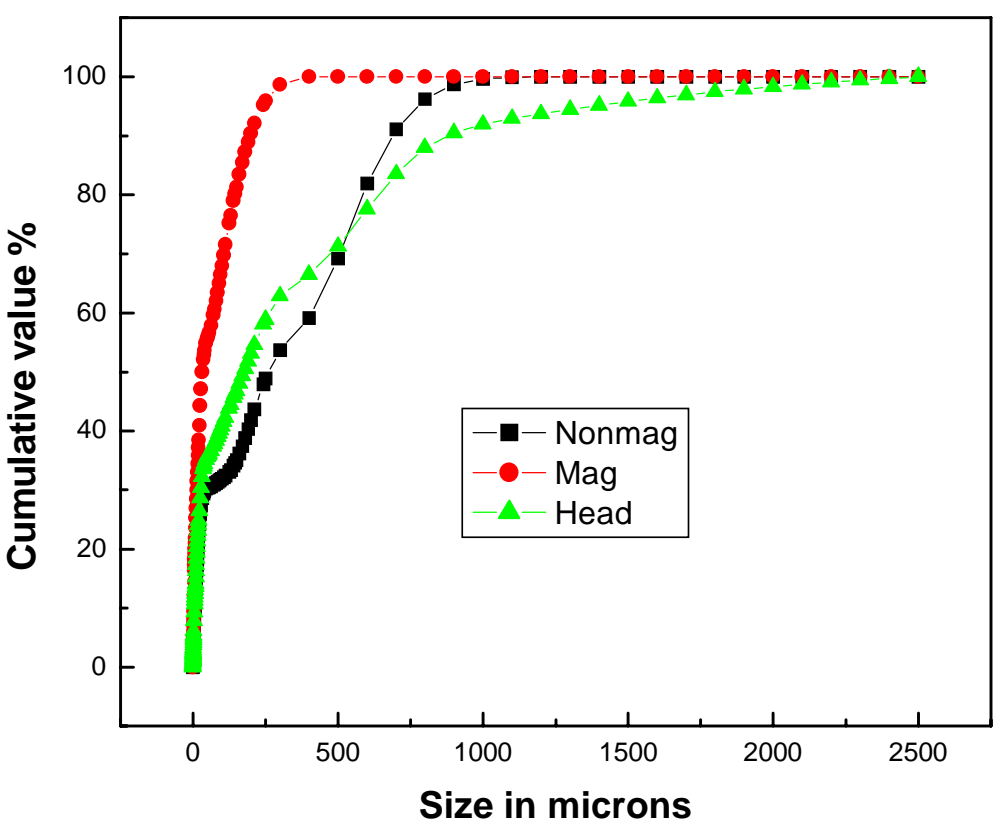

were observed in

the non-magnetic

fraction of both

Figure.2: Particle size analysis of Teri ROM sample along with magnetic and non-magnetic fractions

the samples

(Table 2). In the Teri sample, out of the total heavy minerals, the contribution of ilmenite was found to be nearly $65 \%{ }^{[14]}$. Most of the ilmenite and garnet from both areas show more or less mechanically smooth surfaces.

Table 2: Distribution of minerals in various fractions

\begin{tabular}{|l|c|c|c|c|c|c|c|c|c|}
\hline Sample & \multicolumn{3}{|c|}{$\begin{array}{c}\text { Mineralogy of } \\
\text { Magnetic fraction }\end{array}$} & \multicolumn{3}{c|}{$\begin{array}{c}\text { Mineralogy of } \\
\text { non-magnetic fraction }\end{array}$} & \multicolumn{3}{c|}{ Head (ROM) } \\
\hline & Ilmenite & Garnet & $\begin{array}{c}\text { Others } \\
*\end{array}$ & Ilmenite & Garnet & Others & Ilmenite & Garnet & $\begin{array}{c}\text { Others } \\
* *\end{array}$ \\
\hline Navaladi & 19.56 & 35.01 & 45.43 & --- & --- & 100 & 11.80 & 22.30 & 65.90 \\
\hline Teri & 64.65 & 4.88 & 30.47 & --- & --- & 100 & 37.56 & 1.86 & 60.58 \\
\hline
\end{tabular}

* Others include minerals like pyroxene which are magnetic

**Others: Include zircon, rutile as heavy minerals along with quartz, feldspar

\section{Microscopic studies:}

Microscopic studies show that the placer ilmenite occurs mostly as sub-rounded to sub-angular grains, marked by numerous surface pits, etch marks/grooves, crescentic pits and mesh like patterns. The garnet grains were found to be angular to subangular with occasional subrounded grains and are characterized by conchoidal fracture. The size of the garnet grains was found to be varying from 1000 microns to around 100 microns in 
the Navaladi sample and 500 microns to around 100 microns the Teri sample. Reflected light microscopy studies indicated that the ilmenite from both areas occurs in various shapes and sizes (Figure - 4a). Teri ilmenite contains exsolved laths, streaks and irregular bodies of hematite (Figure - 5a) and vice-versa. The ilmenite (or hematite) lamellae thickness in the hematite (or ilmenite) matrix show conspicuous bimodal distribution. Two generations of hematite or ilmenite can be distinguished on the basis of coarseness or fineness [15]. The Ilmenite-hematite intergrowth gives rise to an emulsion texture in the case of Teri sample. No such intergrowth was observed in the Navaladi sample. In both cases, alteration of ilmenite was observed rarely/occasionally along grain boundaries and/or fractures resulting in an amorphous to crypto- or micro-crystalline mass that resembles leucoxene (Figures - 4b and $5 b$ ). The intensity and mode of alteration was different from grain to grain. Leucoxene was present as patches along grain margins, fractures and rarely within ilmenite due to alteration. The colour of the zircon in these two areas was observed to be reddish brown, which could be attributed to ferruginous stain. Most of these stained grains are fractured
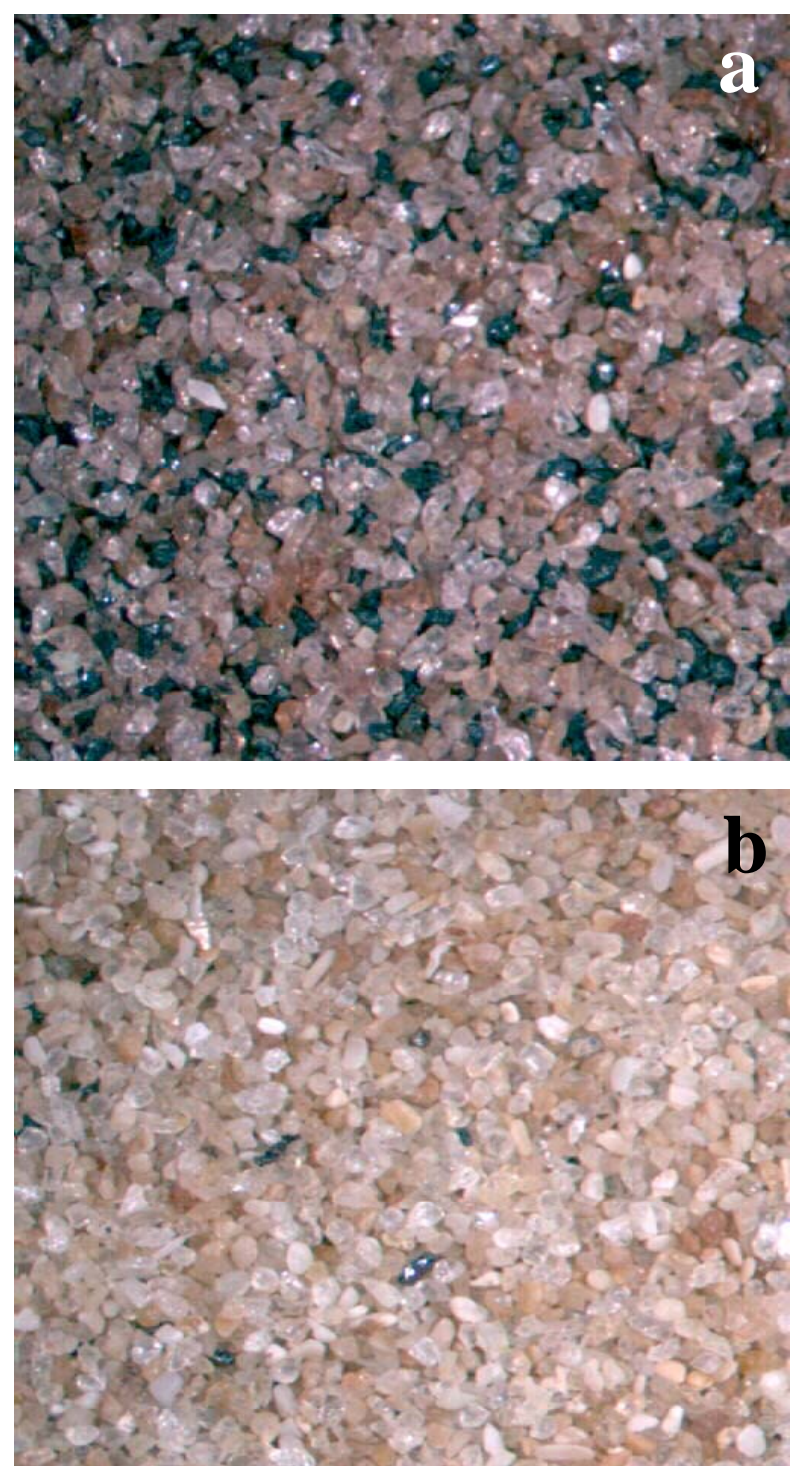

Fig 3a and b: Magnetic fraction of Navaladi showing only garnet (pink) and ilmenite (black) in Fig.3a.

Fig.3b (bottom picture) Non-magnetic fraction in the same size showing quartz and feldspar. stereomicroscope $x 20$

and rounded. The rounded grains are dominant over subrounded and anhedral grains. Very often the zircon is present as well developed crystals with zoning.

\section{Mineral chemistry:}

The concentration of iron and titanium along with minor and trace elements in the ilmenite invariably play a crucial role in the selection/rejection of a specific separation technology. Hence, the major and minor elemental composition, using electron-probe microanalyses (EPMA), of the ilmenite specimens from the Navaladi and Teri was 


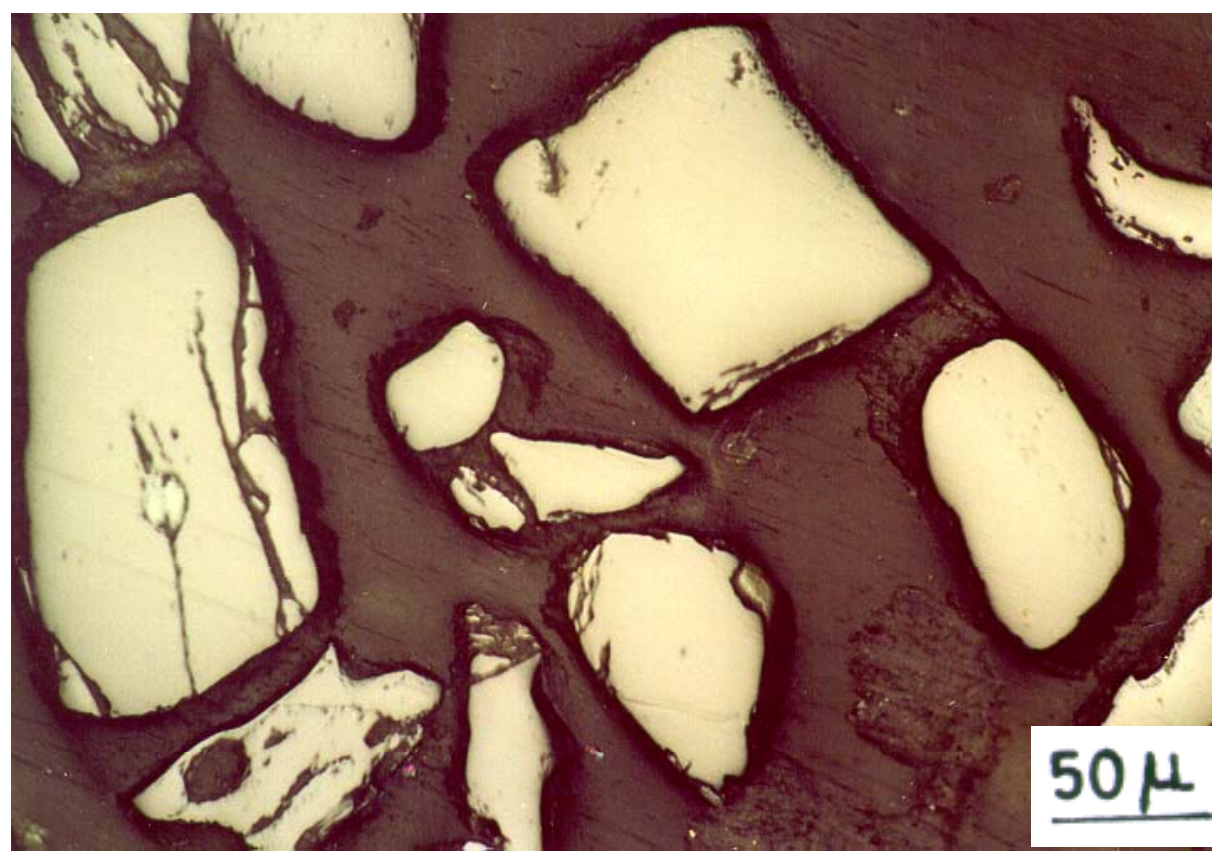

Fig.4a: Various shapes and sizes of ilmenite grains from Navaladi

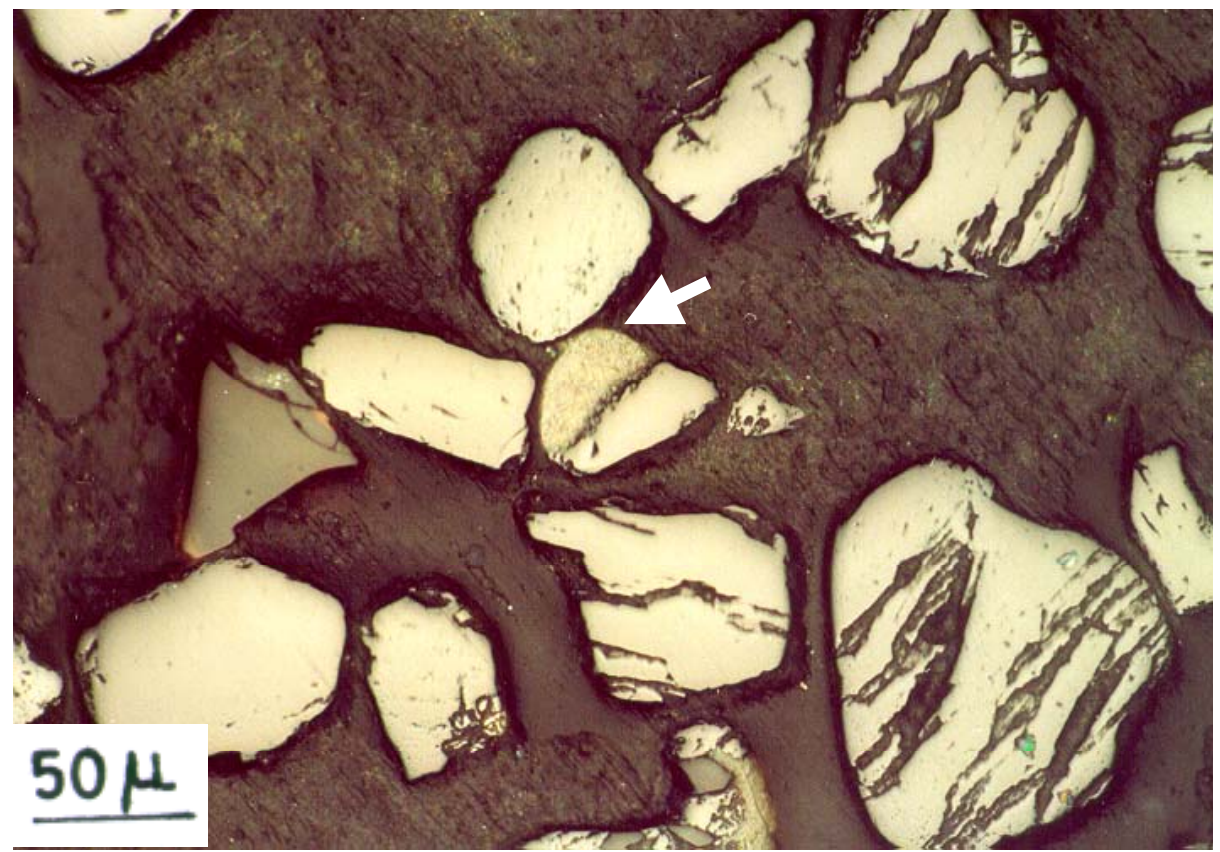

Fig.4b: Alteration of ilmenite grains (shown by arrow) from Navaladi

determined and reported in Table - 3 and Table - 4 respectively. The unaltered ilmenite from both areas shows good stoichiometry of $\mathrm{TiO}_{2}$ (51.387 to $52.035 \%$ for Navaladi and 49.26 to $51.195 \%$ for Teri) and $\mathrm{FeO}$ (45.959 to $46.966 \%$ for Navaladi and 46.84 to $48.622 \%$ for Teri). Significant amounts of $\mathrm{V}_{2} \mathrm{O}_{5} \quad(0.280$ to $0.301 \%$ for Navaladi and 0.263 to $0.288 \%$ for Teri) was recorded while $\mathrm{SiO}_{2}$ and $\mathrm{K}_{2} \mathrm{O}$ were not detected at all in any of the unaltered samples. The presence of significant amounts of magnesium $(0.081$ to $0.916 \%$ for Navaladi and 0.251 to 
$0.301 \%$ for Teri) and manganese $(0.103$ to $0.301 \%$ for Navaladi and 0.443 to $0.717 \%$ for Teri) indicates that the ilmenite from both areas constitute a solid solution series with geikielite $\left(\mathrm{MgTiO}_{3}\right)$ and pyrophanite $\left(\mathrm{MnTiO}_{3}\right)$. As a result of these solid solutions, the $\mathrm{TiO}_{2}$ content of these ilmenites is lower than the ideal value (52.65\%). Mg and $\mathrm{Mn}$ in ilmenite are due to substitution for $\mathrm{Fe}^{2+}$.

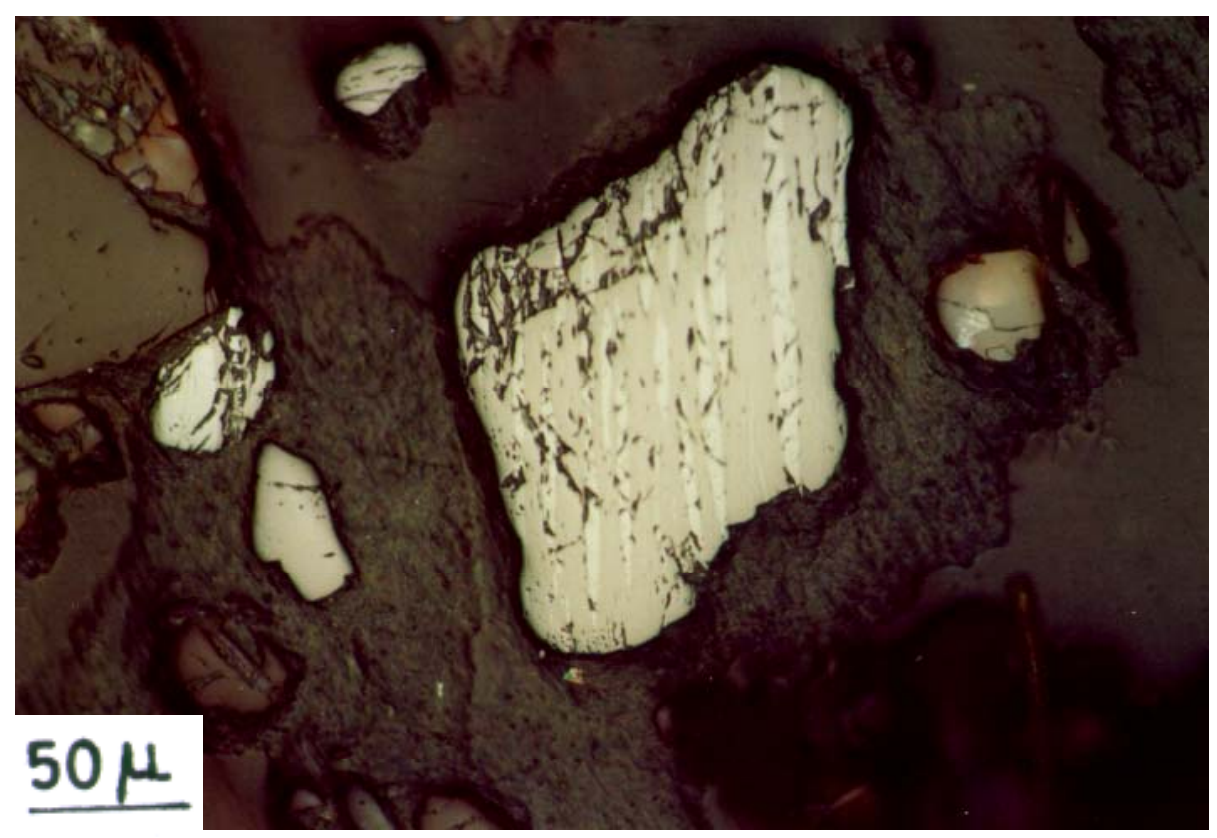

Fig.5a: Hematite (white) and ilmenite (grey) intergrowth of Teri sands

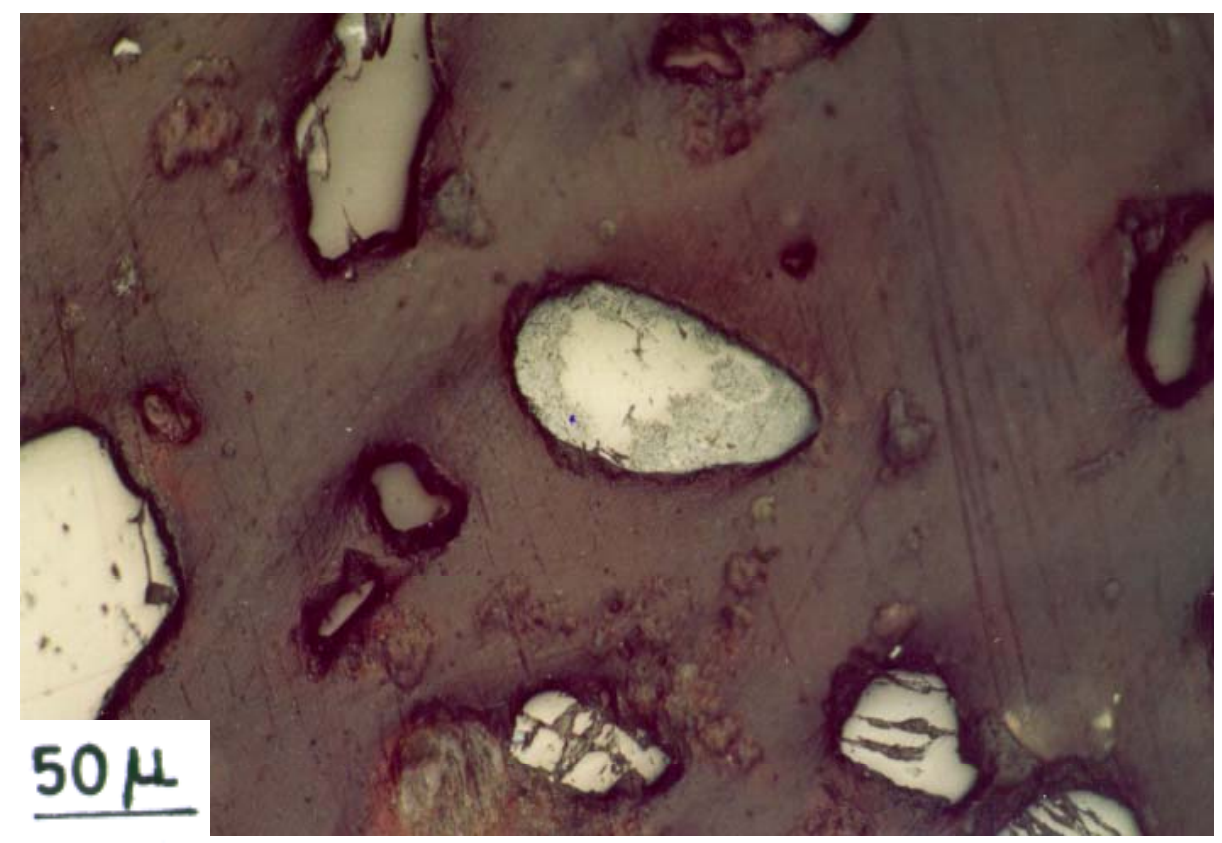

Fig.5b: An altered ilmenite phase has been rimmed around the unaltered ilmenite core of Teri placer sand. 
Mineral chemistry of the associated phases, like garnet and zircon, from both areas was carried out (Table - 4a and - 4b). End member composition of the garnet revealed that almandine is the major species for both samples. In the case of the Teri sample, the hematite grains were also analyzed and some were found to be ilmohematites (Table - 4b). The almandine variety of garnet (also known as abrasive garnet) is an important abrasive mineral extensively used for grinding, sand blasting, and polishing/lapping in glass applications. In addition, it is used in ceramic industries as well.

Table 3a: EPMA data of unaltered as well as altered ilmenite (in wt.\%) of Navaladi sample

\begin{tabular}{|l|c|c|c|c|c|c|c|c|c|}
\hline & Ilmenite & Ilmenite & \multirow{2}{*}{ Ilmenite } & \multicolumn{2}{|c|}{ Altered ilmenite } & \multicolumn{2}{|c|}{ Altered ilmenite } & \multicolumn{2}{c|}{ Altered ilmenite } \\
\cline { 5 - 10 } & & & & $\begin{array}{c}\text { Unaltered } \\
\text { Core }\end{array}$ & $\begin{array}{c}\text { Altered } \\
\text { rim }\end{array}$ & $\begin{array}{c}\text { Unaltered } \\
\text { Core }\end{array}$ & $\begin{array}{c}\text { Altered } \\
\text { rim }\end{array}$ & $\begin{array}{c}\text { Unaltered } \\
\text { Core }\end{array}$ & $\begin{array}{c}\text { Altered } \\
\text { rim }\end{array}$ \\
\hline $\mathrm{FeO}$ & 46.579 & 46.218 & 46.966 & 45.959 & ----- & 46.519 & ------ & 46.875 & ----- \\
\hline $\mathrm{Fe} 2 \mathrm{O} 3$ & ----- & ----- & ----- & ----- & 2.668 & ----- & 8.492 & ----- & 24.262 \\
\hline $\mathrm{TiO} 2$ & 51.738 & 51.624 & 51.639 & 52.035 & 88.833 & 51.387 & 78.522 & 51.796 & 68.936 \\
\hline $\mathrm{Al2O} 3$ & 0.591 & 0.614 & 0.637 & 0.521 & 2.135 & 0.343 & 2.130 & 0.464 & 3.067 \\
\hline $\mathrm{MgO}$ & 0.376 & 0.862 & 0.527 & 0.916 & 1.702 & 0.086 & 2.114 & 0.081 & 0.174 \\
\hline $\mathrm{MnO}$ & 0.238 & 0.301 & 0.256 & 0.103 & 0.039 & 0.143 & 0.028 & 0.262 & 0.002 \\
\hline $\mathrm{ZnO}$ & 0.061 & 0.026 & 0.100 & 0.003 & ---- & ----- & 0.026 & 0.059 & 0.038 \\
\hline $\mathrm{Cr} 2 \mathrm{O} 3$ & 0.047 & 0.162 & 0.033 & 0.049 & 0.149 & 0.002 & 0.146 & 0.049 & 0.143 \\
\hline $\mathrm{V} 2 \mathrm{O} 5$ & 0.289 & 0.280 & 0.289 & 0.301 & 0.512 & 0.290 & 0.473 & 0.297 & 0.429 \\
\hline $\mathrm{SiO} 2$ & ----- & ----- & ----- & ----- & 1.798 & ----- & 2.675 & ----- & 1.161 \\
\hline $\mathrm{Na} 2 \mathrm{O}$ & ----- & 0.049 & ----- & ----- & 0.221 & ----- & 0.115 & ----- & 0.236 \\
\hline $\mathrm{CaO}$ & 0.001 & 0.391 & ----- & 0.013 & 0.723 & 0.129 & 0.340 & 0.029 & 0.190 \\
\hline Total & 99.920 & 100.527 & 100.447 & 98.900 & 98.780 & 98.899 & 95.061 & 99.912 & 98.638 \\
\hline
\end{tabular}

Table 3b: EPMA data of garnet (in wt.\%) of Navaladi sample

\begin{tabular}{|c|c|c|c|c|}
\hline & Garnet & Garnet & Garnet & Zircon \\
\hline $\mathrm{SiO} 2$ & 39.454 & 38.468 & 38.115 & 31.387 \\
\hline $\mathrm{Al} 2 \mathrm{O} 3$ & 20.677 & 20.621 & 20.647 & ----- \\
\hline $\mathrm{FeO}$ & 29.578 & 33.056 & 30.540 & 0.003 \\
\hline $\mathrm{MgO}$ & 7.605 & 4.357 & 6.017 & 0.053 \\
\hline $\mathrm{MnO}$ & 0.357 & 1.011 & 0.622 & 0.010 \\
\hline $\mathrm{CaO}$ & 0.811 & 1.287 & 1.840 & 0.003 \\
\hline $\mathrm{Na} 2 \mathrm{O}$ & 0.047 & ----- & ----- & ----- \\
\hline $\mathrm{TiO} 2$ & 0.052 & 0.064 & 0.049 & ----- \\
\hline Cr2O3 & 0.031 & 0.087 & 0.132 & 0.042 \\
\hline $\mathrm{ZnO}$ & 0.122 & 0.049 & ----- & ----- \\
\hline $\mathrm{ZrO} 2$ & ----- & ----- & ----- & 66.987 \\
\hline HfO2 & ----- & ----- & ----- & 0.610 \\
\hline Total & 98.734 & 99.000 & 97.962 & 99.097 \\
\hline \multicolumn{5}{|c|}{ Formulae based on $24(\mathrm{O})$} \\
\hline $\mathrm{Si}$ & 6.1904 & 6.1546 & 6.0994 & \\
\hline $\mathrm{Al}$ & 3.8240 & 3.8888 & 3.8945 & \\
\hline $\mathrm{Fe}$ & 3.8812 & 4.4231 & 4.0873 & \\
\hline $\mathrm{Mg}$ & 1.7788 & 1.0392 & 1.4354 & \\
\hline $\mathrm{Mn}$ & 0.0475 & 0.1371 & 0.0844 & \\
\hline $\mathrm{Ca}$ & 0.1364 & 0.2206 & 0.3155 & \\
\hline $\mathrm{Na}$ & 0.0142 & ----- & $\begin{array}{ll}---- \\
\end{array}$ & \\
\hline $\mathrm{Ti}$ & 0.0062 & 0.0076 & 0.0059 & \\
\hline $\mathrm{Cr}$ & 0.0038 & 0.0110 & 0.0167 & \\
\hline $\mathrm{Zn}$ & 0.0141 & 0.0058 & $\begin{array}{ll}---- \\
\end{array}$ & \\
\hline Total & 15.8878 & 15.8878 & 15.9391 & \\
\hline
\end{tabular}


Table 4a: EPMA data of unaltered as well as altered ilmenite (in wt.\%) of Teri sample

\begin{tabular}{|c|c|c|c|c|c|c|c|c|}
\hline \multirow{2}{*}{} & \multirow{2}{*}{ Ilmenite } & \multirow{2}{*}{ Ilmenite } & \multicolumn{2}{|c|}{ Altered ilmenite } & \multicolumn{2}{c|}{ Altered ilmenite } & \multicolumn{2}{c|}{ Altered ilmenite } \\
\cline { 4 - 9 } & & & $\begin{array}{c}\text { Unaltered } \\
\text { Core }\end{array}$ & $\begin{array}{c}\text { Altered } \\
\text { rim }\end{array}$ & $\begin{array}{c}\text { Unaltered } \\
\text { Core }\end{array}$ & $\begin{array}{c}\text { Altered } \\
\text { rim }\end{array}$ & $\begin{array}{c}\text { Unaltered } \\
\text { Core }\end{array}$ & $\begin{array}{c}\text { Altered } \\
\text { rim }\end{array}$ \\
\hline $\mathrm{FeO}$ & 48.234 & 48.622 & 46.840 & ----- & 47.675 & ----- & 47.937 & ----- \\
\hline $\mathrm{Fe2O} 3$ & ----- & ----- & ----- & 2.638 & ---- & 18.154 & ----- & 8.102 \\
\hline $\mathrm{TiO} 2$ & 50.209 & 49.260 & 51.195 & 88.638 & 50.340 & 74.422 & 49.754 & 87.493 \\
\hline $\mathrm{Al2O} 3$ & 0.808 & 0.483 & 0.408 & 2.589 & 0.454 & 2.436 & 0.369 & 2.247 \\
\hline $\mathrm{MgO}$ & 0.251 & 0.301 & 0.758 & 0.904 & 0.509 & 1.149 & 0.374 & 0.714 \\
\hline $\mathrm{MnO}$ & 0.659 & 0.717 & 0.610 & ----- & 0.434 & 0.066 & 0.443 & ---- \\
\hline $\mathrm{ZnO}$ & 0.077 & ----- & 0.020 & ----- & 0.007 & 0.048 & 0.016 & ----- \\
\hline $\mathrm{Cr} 2 \mathrm{O} 3$ & 0.009 & 0.005 & 0.003 & 0.153 & 0.019 & 0.133 & 0.073 & 0.235 \\
\hline $\mathrm{V} 2 \mathrm{O} 5$ & 0.288 & 0.281 & 0.263 & 0.532 & 0.280 & 0.455 & 0.286 & 0.523 \\
\hline $\mathrm{SiO} 2$ & ----- & ----- & ----- & 1.382 & ----- & 1.165 & ----- & 1.329 \\
\hline $\mathrm{Na} 2 \mathrm{O}$ & ----- & ----- & ----- & 0.334 & ---- & 0.030 & ----- & 0.139 \\
\hline $\mathrm{CaO}$ & 0.020 & & 0.011 & 0.369 & 0.001 & 0.211 & 0.003 & 0.153 \\
\hline Total & 100.555 & 99.669 & 100.109 & 97.224 & 99.719 & 98.267 & 99.255 & 98.935 \\
\hline
\end{tabular}

Table 4b: EPMA data of associated phases (in wt.\%) of Teri sample

\begin{tabular}{|c|c|c|c|c|c|c|}
\hline & Garnet & Zircon & Quartz & Hematite & $\begin{array}{c}\text { Ilmo- } \\
\text { hematite }\end{array}$ & Rutile \\
\hline $\mathrm{FeO}$ & 29.414 & 0.054 & 0.032 & ----- & ----- & 0.109 \\
\hline $\mathrm{Fe} 2 \mathrm{O} 3$ & ----- & ----- & ----- & 96.089 & 77.013 & ----- \\
\hline $\mathrm{TiO} 2$ & 0.158 & ----- & 0.027 & 0.245 & 22.045 & 98.231 \\
\hline $\mathrm{Al2O} 3$ & 21.586 & ----- & ----- & 0.989 & 0.657 & 1.155 \\
\hline $\mathrm{MgO}$ & 10.027 & ----- & ----- & ----- & 0.004 & ----- \\
\hline $\mathrm{MnO}$ & 0.317 & ----- & 0.022 & 0.205 & 0.213 & 0.033 \\
\hline $\mathrm{ZnO}$ & ----- & ----- & 0.088 & 0.034 & 0.007 & 0.023 \\
\hline $\mathrm{Cr} 2 \mathrm{O} 3$ & 0.023 & 0.009 & ----- & 0.207 & 0.201 & 0.401 \\
\hline $\mathrm{V} 2 \mathrm{O} 5$ & 0.001 & 0.002 & 0.002 & 0.003 & 0.105 & 0.582 \\
\hline $\mathrm{SiO} 2$ & 38.003 & 31.596 & 99.159 & 0.098 & 0.009 & ------ \\
\hline $\mathrm{Na} 2 \mathrm{O}$ & ----- & ----- & 0.011 & ----- & ----- & ----- \\
\hline $\mathrm{K} 2 \mathrm{O}$ & ----- & 0.010 & ----- & 0.003 & ----- & ----- \\
\hline $\mathrm{CaO}$ & 0.764 & ----- & ----- & 0.001 & 0.017 & 0.007 \\
\hline $\mathrm{ZrO} 2$ & ----- & 67.019 & ----- & ----- & ----- & ----- \\
\hline $\mathrm{HfO} 2$ & ----- & 0.584 & ----- & ----- & ----- & ----- \\
\hline & 100.293 & 99.274 & 99.341 & 97.874 & 100.276 & 100.541 \\
\hline
\end{tabular}

Major and minor elemental analyses of the altered and unaltered portions of three different ilmenite grains from both the areas were carried out (Tables - 3 and - 4). The analyses of unaltered ilmenite portions compared well with natural ilmenites. The altered ilmenite portions are enriched in $\mathrm{TiO}_{2}$ (68.936 to $88.833 \%$ for Navaladi and 74.422 to 88.638\% for Teri), MgO (0.174 to $2.114 \%$ for Navaladi and 0.714 to $1.149 \%$ for Teri), $\mathrm{Al}_{2} \mathrm{O}_{3}$ (2.135 to $3.067 \%$ for Navaladi and 2.247 to $2.589 \%$ for Teri), $\mathrm{Cr}_{2} \mathrm{O}_{3}$ (0.143 to $0.149 \%$ for Navaladi and 0.133 to $0.235 \%$ for Teri), $\mathrm{SiO}_{2}$ (1.161 to $2.675 \%$ for Navaladi and 1.165 to $1.382 \%$ for Teri), $\mathrm{V}_{2} \mathrm{O}_{5}$ ( 0.429 to $0.512 \%$ for Navaladi and 0.455 to $0.532 \%$ for Teri) and $\mathrm{Na}_{2} \mathrm{O}$ (0.115 to $0.236 \%$ for Navaladi and 0.030 to $0.334 \%$ for Teri) and decreased in $\mathrm{MnO}$ and $\mathrm{FeO}$ content. The alteration starts with the removal of $\mathrm{Fe}^{+2}$ then 
the electrostatic charge is balanced by oxidising the remaining iron. The removal of iron is compensated by the addition of other elements ( $\mathrm{Ti}, \mathrm{Mg}, \mathrm{Al}, \mathrm{Si}$ ) into the structure along with $(\mathrm{OH})$ ions into the mineral lattice. Thus, the sum total of the percentages from the altered portions of ilmenite varies from $95.061 \%$ to $98.780 \%$ for Navaladi and from 97.224\% to $98.935 \%$ for Teri, which may be due to the incorporation of hydroxyl ions into the structure during weathering. Similar observations have also been made by many authors ${ }^{[2,5,16-17]}$.

Dissolution and/or oxidation of iron from ilmenite in natural water or in acidic water leads to an enrichment of titanium and other elements in the residuum, which may be the main cause for ilmenite alteration ${ }^{[18]}$. Though ilmenite alteration is neither uniform nor continuous, the weathering mechanism is illustrated as a two stage process

${ }^{[16]}$ and/or a multistage process ${ }^{[10-11]}$. However, the present mineral chemistry suggests that the initial step involving a ferrous-ferric iron transformation stage is relatively advanced (indicated by a relatively low content of ferrous iron or removal of iron and enhancement of titanium), which is a common low temperature geochemical process. In general, such a process leads to incomplete alteration of ilmenite and the co-existence of ilmenite and leucoxene. The composition and grade/quality changes noticed in these placer ilmenites could only be due to the exogenic processes undergone by the mineral after its release from those Precambrian metasedimentary crystalline parent rocks. The heavy mineral assemblage in this sector is suggestive of provenance consisting principally of high-grade metamorphic (granulite facies) rocks, principally of khondalite (garnet-sillimanite-graphite-gneisses), charnokites and granitic gneisses (unclassified crystalline rocks), bordered by the sedimentary rocks exposed along the eastern coastal plains which are the rock types of Tamilnadu ${ }^{[14]}$. However, the extent of alteration depends on the geological history of the deposit and also the weathering environments ${ }^{[2}$,

11]. The degree of alteration of different ilmenite deposits in the world is quite varied; those of Zululand (South Africa) and Brazil being altered relatively very little but those of Australia and Florida (U.S.A.) show extensive alteration ${ }^{[11,19]}$. Similarly in the case of the Indian beach sand ilmenites of the different regions; Kerala state ilmenite underwent maximum alteration while the Tamilnadu state ilmenite was altered moderately and Orissa ilmenites of the Chatrapur coast have undergone the least weathering ${ }^{[3]}$.

\section{DISCUSSION AND CONCLUSIONS}

\section{Mineralogy:}

Teri sample contains higher amounts of ilmenite and minor amounts of garnet while the Navaladi sample contains higher amounts of garnet and good amount of ilmenite. In addition both samples contain traces of rutile and zircon, with hematite observed in the Teri sample. The iron content in the ilmenite concentrate is likely to be more in the Teri sample due to the presence of exsolved hematite. The hematite lamellae in the ilmenite and ilmenite lamellae in hematite indicate that they are exsolved from $\mathrm{FeTiO}_{3}-\mathrm{Fe}_{2} \mathrm{O}_{3}$ solid solution ${ }^{[20]}$. The presence of ilmo-hematite along with hematite and ilmenite also attests that they are exsolved from $\mathrm{FeTiO}_{3}-\mathrm{Fe}_{2} \mathrm{O}_{3}$ solid solution. The two 
generations of ilmenite and hematite may indicate different periods of crystallization ${ }^{[15]}$. The coarser first generation lamellae were probably formed at higher temperatures $\left(530^{\circ} \mathrm{C}-600^{\circ} \mathrm{C}\right)$ by a fast diffusion process, where-as the finer second generation lamellae may represent a later stage of crystallization in the range of $450^{\circ} \mathrm{C}-500^{\circ} \mathrm{C}$ and might have been produced by slow diffusion processes ${ }^{[20-21]}$. The ilmenites of both the areas are altered along grain boundaries and fractures. This alteration leads to formation of leucoxene. Electron probe microanalysis data indicate that the ilmenite is in solid solution with pyrophanite and geikielite and the alteration leads to enrichment of $\mathrm{TiO}_{2}$, $\mathrm{MgO}, \mathrm{Al}_{2} \mathrm{O}_{3}, \mathrm{Cr}_{2} \mathrm{O}_{3}, \mathrm{SiO}_{2}, \mathrm{~V}_{2} \mathrm{O}_{5}$ and $\mathrm{Na}_{2} \mathrm{O}$ with loss of iron and manganese oxides. Trace elements like chromium, vanadium, calcium and magnesium in the ilmenite are with-in acceptable limits for the processing industry. These alteration products could be due to the exogenic processes that operated on these ilmenites after their release from the parent rocks. The studies further indicated that the alteration of ilmenite is not uniform and the extent of alteration varies from grain to grain. Almandine is the major species of garnet revealed from the mineral chemistry for both areas. The natural size range of these almandine garnets indicates that they are ideally suited for sand blasting or water jet cutting purposes.

As mentioned above, the source rocks of these placer minerals are the charnokite and khondalite group of rocks of the Precambrian Eastern Ghats complex, which crops out widely in the Tamilnadu region. The Eastern Ghats rocks of Precambrian contain ilmenite, zircon and garnet among others as minor accessory minerals. Hence, the Eastern Ghats provenance appears to be the major source for these mineral assemblages in these two regions.

\section{Implications in processing:}

Ilmenite, which is gradually converting to leucoxene in these two deposits under oxidising conditions, leaving enriched residue of $\mathrm{TiO}_{2}$ and $\mathrm{SiO}_{2}$ along with others, results in the formation of porous grains of altered ilmenite/leucoxene. The pores may remain open or may get filled by a variety of secondary minerals, which affect their grade/quality. These porous grains have low density and low magnetic susceptibility (because of changing iron content) leading to concentration problems. Wort and Jones studied the changes in magnetic susceptibility that takes place when an ilmenite alters and opined that the changes are related to the chemical composition ${ }^{[22]}$. Such differences in physical properties between altered/oxidised ilmenite and fresh/unaltered ilmenite were often very great and have a definite influence on beneficiation/metallurgical down stream processes. The altered or oxidised ores behave very differently in the processes compared to the fresh unaltered ores. It is well known that ilmenite is soluble in $\mathrm{H}_{2} \mathrm{SO}_{4}$ where as rutile is not. However, the degree of solubility of ilmenite varies depending on the extent of alteration. Regardless of the higher $\mathrm{TiO}_{2}$ content in the altered ilmenite, its solubility in $\mathrm{H}_{2} \mathrm{SO}_{4}$ decreases with increasing degree of alteration ${ }^{[23]}$. In other words, the high ferric iron content of the altered ilmenite clearly demands a reduction process rather than a sulphate process for $\mathrm{TiO}_{2}$ production ${ }^{[13,24]}$. Similarly the rate of reduction and size of the iron particles formed, decreases (during reduction) with increasing degree of 
weathering of the ilmenite concentrate ${ }^{[25]}$. In other words stoichiometric ilmenite reduces faster than pseudorutile, which is a product of weathering. Hence, the degree of weathering or alteration can be an indicator of a minerals' economic value. Compositional characterization by instrumental techniques as used in this study, would not only help us to adopt better methods for industrial processing, but also facilitate the production of different grades of synthetic rutile.

\section{Acknowledgements:}

The authors wish to acknowledge Indian Ocean Garnet Sands Pvt. Limited, Tuticorin for providing facilities for collection of the samples and Council of Scientific and Industrial Research, India for financial assistance extended under Network project (CMM - 0023). Thanks are also due to The Director, National Metallurgical Laboratory for his keen interest and permission to publish this work.

\section{References}

1. Mookherjee, A. (1999) Ore genesis: A holistic approach. Allied publishers, New Delhi.

2. Suresh Babu, D.S., Thomas, K.A., Mohan Das, P.N. and Damodaran, A.D. (1994) Alteration of ilmenite in the Manavalakurichi deposit, India. Clays and Clay Minerals, 42, pp.567-571.

3. Suresh Babu, D. S., Das, D., Sudarsan, M., Reddy, V.R., Chintalapudi, S.N. and Majumdar, C.K. (1996) ${ }^{57} \mathrm{Fe}$ Mössbauer studies on natural ilmenites. Ind. Jour. of Pure and Applied Physics, 34, pp.474-479.

4. Suresh Babu, D.S. and Mohan Das, P.N. (1999) Mineralo-chemical assessment of ilmenites from the three Indian placers. Trans. Indian Inst. Met., 52, pp.73-79.

5. Rao, D.S., Murthy, G.V.S., Rao, K.V. Das, D. and Chintalapudi, S.N. (2002) Alteration characteristics of beach placer ilmenite from the Chatrapur coast, Orissa, India. Jour. Applied Geochemistry, Vol.4, No.1, pp.47-59.

6. Bailey, S.W., Cameron, E.N., Spedden, H.R. and Weege, R.J. (1956) The alteration of ilmenite in beach sands. Econ. Geol., 51, pp.263-279.

7. Temple, A.K. (1966) Alteration of ilmenite. Econ. Geol., 61, pp.695-714.

8. Wort, M. J. and Jones, M.P. (1980) X-ray diffraction and magnetic studies of altered ilmenite and pseudorutile. Mineral. Mag., 43, pp.659-663.

9. Mitra, S., Ahmed, S.S. and Moon, H.S. (1992) Mineralogy and chemistry of the opaque of Cox's Bazar (Bangladesh) beach sands and the oxygen fugacity of their provenance. Sedimentary Geol., 77, pp.235-247.

10.Frost, M.T., Grey, I.E., Harrowfield, I.R. and Mason, K. (1983) The dependence of alumina and silica contents on the extent of the alteration of weathered ilmenites from Western Australia. Mineral. Mag., 47, pp.201-208.

11.Hugo, V. E. and Cornell, D. H. (1991) Altered ilmenites in Holocene dunes from Zululand, South Africa, Petrographic studies for multistage alteration. South Africa Jour. Geol., 94, pp.365-378. 
12.Ramakrishnan, C., Mani, R. and Suresh Babu, D.S. (1997) Ilmenite from the Chavara deposit, India: a crictical evaluation. Miner. Mag., 61, pp.233-242.

13.Chernet, T. (1999a) Applied mineralogical studies of the Koivusaarenneva ilmenite deposit, Kalvia, Western Finland, with special reference on the altered part of the ore. Chronique De La Rescherche Miniere, 535, pp.19-28.

14.Chandrasekharan, S. and Murugan, C. (2001) Heavy minerals in the beach and the coastal red sand (Teris) of Tamilnadu. Exploration and Research for Atomic Minerals, 13, pp.87-109.

15.Ramdhor, P.F. (1969) The ore minerals and their intergrowth. Pergamon press, Oxford London, 1174p.

16.Grey, I.E. and Reid, A. F. (1975) The structure of the pseudo-rutile and its role in the alteration of ilmenite. Amer. Mineral., 60, pp.898-906.

17.Anand, R.R. and Gilkes, R. J. (1984) Weathering of ilmenite in a lateritic Pallid zone. Clays and Clay Minerals, 32, pp.363-374.

18.Dimanche, F. and Bartholome, P. (1976) The alteration of ilmenite in sediments. Minerals Sci. Engg., 8, pp.187-201.

19.Haseeb, A.S.M., Hug, M. Z. and Kurny, A.S.W. (1997) Characterization of Bangladesh ilmenite and study of its reduction mechanism by X-ray diffraction. Trans. Instn. Min. Metall., Sec.C, 106, pp.39-43.

20.Acharya, B.C. Panigraphy, P.K., Nayak, B.B. and Sahoo, R.K. (1998) Heavy mineral placer deposits of Ekakula beach Gahiramatha, Orissa, India. Resource Geology, V.48, No.2, pp.125-136.

21.Ahmed, S., Pal, T. and Mitra, S. (1992) Ilmenite from Cox’s Bazar beach ands, Bangladesh:Their intergrowths. Jour. Geol. Soc. Ind., vol.40, 29-41.

22.Wort, M.J. and Jones, M.P. (1981) Magnetic properties of ilmenite detrital altered ilmenite and pseudorutile. Trans. Instn. Min. Metall., Sec. C, 90, C130-137.

23.Sinha, H.N. (1979) Solubility of titanium minerals. Int. Conf. Advanced Chem. Metallurgy, 2, pp.1-16.

24.Chernet, T. (1999b) Applied mineralogical studies on Australian sand ilmenite concentrate with special reference to its behavior in the sulphate process. Min. Engg., 12, pp.485-495.

25.Gupta, S.K., Rajakumar, V. and Grieveson, P. (1988) The influence of weathering on the reduction of ilmenite with carbon. Metal. Trans., 20B, 735-745. 